\title{
The Relation between Notary Profession Secrecy and TKM Report through Grips System
}

\author{
Andreas Albertus Andi Prajitno \\ Faculty of Law, Pelita Harapan University \\ J1. Ahmad Yani, Dukuh Menanggal, Surabaya, East Java 60234. \\ E-mail: andiprajitno@yahoo.com \\ DOI: 10.29322/IJSRP.11.06.2021.p11463 \\ http://dx.doi.org/10.29322/IJSRP.11.06.2021.p11463
}

\begin{abstract}
Notary is one of general occupation that can watch over cash flow within people who are willing to corrupt some amount of treasury by some attempts such as corruption, theft, manipulation, drugs selling, and etc. The money retrieved from such crimes are used to fund illegal activity such as money laundry and terrorism. Problem of this study found out that the role of notary is very important for national security toward money laundry and terrorism prevention. Juridical normative is used as method of study within statue approach, law source used in this study is constitution. Data is analysed by using inductive technique. Notary, in accomplishing its duty, who is creating authentic deed in civil law could be misused by users who are not responsibility on their action and endangered national stability, huge amount of money and indefinite source of it will make great impact toward nation. That is why, Indonesian government commence GRIP system (Gathering Reports and Information Processing System), it forces notary who detect indefinite treasury and report it immediately to government institution PPATK (finance transaction report and analysis centre). It is mandatory for notary to report indefinite transaction which is offered to them as project. Such regulation does not against oath office of notary occupation and its occupation secrecy which is known in Indonesia as UUJN. Because, it concerns with justice and national security matter, general and social benefit principle, which are first priority toward national and international concern.
\end{abstract}

Keywords- Money Laundering and Terrorism, Notary Profession Secrecy, Report, Grips, Security, Benefit, and Social Principle.

\section{INTRODUCTION}

Terrorism and radicalism are cross-nation threats which develop its networks within vast area and closed activity ${ }^{1}$. Thus, it takes collective action through capability collaboration and constructive intensive, and concrete cross-nation interaction. Money laundering and terrorism are such double never ending $\operatorname{crimes}^{2,3}$, the recent event that give a shock toward all nations are the panama papers which is secret finance document from law institution of panama.

Country plays its active role to implement standard action to fight against many laundering a terrorism. In general, the actor of money laundering is trying to hide the financial resource of their treasury by using many options in order to compound the law enforcer to track the indefinite treasury, so the criminals could use the money in legal or illegal way freely. Money laundering does not only threaten stability, integrity, and financial system ${ }^{4}$, but also social pillars, national security that follow constitution of

\footnotetext{
${ }^{1}$ Smith, A. G. (2018). How Radicalization to Terrorism Occurs in the United States: What Research Sponsored by the National Institute of Justice Tells Us. Washington, DC: NIJ National Institute of Justice, p. 8-9

2 Handoko, A. (2019). Analisis Kejahatan Terorisme Berkedok Agama. SALAM Jurnal Sosial \& Budaya Syar'i. 6(2), p. 157

3 Amrullah, M. A. (2003). Pencucian Uang dan Kejahatan Terorganisir. JURNAL HUKUM, 22(10), p. 138

${ }^{4}$ Dobrowolski, Z., and Sulkowski, L. (2019). Implementing a Sustainable Model for Anti-Money Laundering in the United Nations Development Goals. Sustainability, 12(244), p. 2-3
}

This publication is licensed under Creative Commons Attribution CC BY.

http://dx.doi.org/10.29322/IJSRP.11.06.2021.p11463 
republic of Indonesia 1945. Nowadays, the development of money laundering technique becomes more complex by crossing jurisdiction limits, and use varies of ways by using non-finance institution and every possible sectors.

Money laundering is an organized crime by hiding financial track record o indefinite money which is result of civil law violation ${ }^{5,6}$. The actor transforms the money into one of its legal sources of income, which is clearly defined in black law dictionary "terms used to describe investment or other transfer of money flowing form racketeering, drug transaction, and other illegal sources into legitimate channels so that is original source cannot be traced"7 (Black, 1990:884).

Money laundering is a crime executed by individual or corporation by placing, transferring, locating, using, giving, entrusting, and bringing to other country, transforming into other luxury, changing the currency or deed some amount of indefinite treasury, or other action toward the treasure which comes from violation of civil law in order to hide the financial track record of the treasure, which is illegal money and it makes the money looks like one of legal source of income.

"The process by which a person conceal or disguise the identity or the origin of illegall obtainne so that they appear to have originated from legitimate sources* UNODC and IMF Model Law on Money Laundering and Financing Terrorism"

According to Husein ${ }^{8}$, there are several negative impact toward some factors as result of money laundering trend, namely:

1. Endangered financial institution integrity, because the institutions may be charged with liquidity if it is proven in managing indefinite treasury.

2. It will disturb legal private sector, the criminals who are mixing legal and illegal finance of front companies, it is meant to hide the track record of indefinite money which is result of crime. Those front companies had access toward illegal financing institution, they used it to support their products and sell it at very low price, and it will destroy other legal company who follow constitution.

3. Dismissing government control toward financial policy.

4. It creates economic distortion and instability, because the money laundering criminals are not interested in legal infestation, they prefer shortcut within large profit that would kill national stability.

5. Government will lose some of its taxes rate because money laundering will destroy other legal corporation, it will pressurize the government to collect the taxes harder than before.

6. It endangered privatisation attempts by government that try to claim their most stock in a corporation; it also endangered economic reformation by privatisation of corporation owned by government. Those criminals' organisations are trying to buy corporation stock with higher offer in price by using indefinite source of money.

7. It will destroy national reputation in international that will lead to distrust in stock market because the high amount of indefinite money in a country or financial crime will destroy the reputation of the nation.

8. It will ignite higher social cost.

Indefinite report of illegal finance could be a proof that it will be appeared after one of those negative impacts occurred. The total report of indefinite money starting from 2013 to 2018, according to vice president of finance transaction report and analysis centre of Indonesia PPATK, Dian Adiana Rae, is 414.299 reports of indefinite source of money. After the publication of Money Laundering Law TPPU, the amount is decreased into 350.375 reports.

In order to exterminate money laundering activity, regional and international cooperation is needed through bilateral or multilateral interaction Thus, the money laundering activity that plays huge amount of money could be decreased over time.

Especially for Indonesia, cooperation between institutions that are vulnerable to money laundering activity such as finance, bank, cooperation, association, foundation, LSM, lawyer, public accountant, and notary. These institutions are very fragile to be used as money laundering media from indefinite source of money. This study would be best to communicate the phenomena in the scope

5 Eleanora, F. N. (2011). Tindak Pidana Pencucian Uang. Jurnal Hukum, XXVI(2), p. 67

6 Alkostar, A. (2013). Penerapan Undang-Undang Tindak Pidana Pencucian Uang dalam Hubungannya dengan Predicate Crimes. MMH, 42(1), p. 48

7 Black, H. C. (1990). Black's Law Dictionary Sixth Edition, St. Paul Minn: West Publisihing Co, p. 884

${ }^{8}$ Husein, Y. (2007). Bunga Rampai Anti Pencucian Uang, Cet. 1, Bandung: Books Terrace \& Libertty, p. 83-84

This publication is licensed under Creative Commons Attribution CC BY. 
of notary in Indonesia to the broader area of viewers in the same and related field.

\section{RESEARCH DESIGN}

Research type used in this study is juridical normative. It is a research within scientific based procedure in order to find logical answer. The study uses statue approach. Primary law resource used in this study is law number 8 of 2010, notary profession law number 2 of 2014. Next, the secondary law resource is government regulation, president regulation, and other seminar documentation. Data collection and management technique is implemented by identifying the regulation by inductive data analysis technique9.

\section{DISCUSSION}

In Indonesia, notary is one of general official whose main duty is to conduct written legal deed in civil law within vast policy, it means all legal civil action whom duty is not taken over other official and only managed by notary. It is regulated in law number 2 of 2014 about amendment of law number 30 of 2004 about notary occupation article 15 Act 1, act 2, and act 3 .

(Article 15)

(1) Notary has authorities in conducting authentic deed of all action, agreement, and decision which is enforced by constitution and/or enforced by responsible actor which will be stated in authentic deed, ensure the release date of deed, save deed, provide grosses, copy, and, cited deed, as long as the conducting deed process does not include other person or official which is stated by constitution.

(2) Beside authorities stated in act 1, notary is also responsible for;

a. Legalised signature and publication date by registering it in special book;

b. Conducting the legal deeds in special book;

c. Provide the copy of original deeds that contains exact information as original deed;

d. Legalised the copied version of deeds;

e. Provide legal socialisation about deeds;

f. Conduct land deed; or

g. Conduct auction deed

h. Apart from authorities stated in act 1 and act 2, notary has other authorities which is stated in constitution.

Before executing their duties mentioned above, they must first take the oath which is witnessed by government as same as other state officials which is mentioned in UUJN article 4, it states;

(Article 4)

(1) Before taking their duties, notary must say the oath based on their religion on front of ministry or other officials in charge.

(2) Oath which is mentioned in act 1 is sentenced;

"I swear / promise:

That I will be obedient and loyal to the Republic of Indonesia, Pancasila and the 1945 Constitution of the Republic of Indonesia, the Law on Notary Position and other laws and regulations. That I will carry out my position with trust, honesty, accuracy, independence and impartiality.

That I will maintain my attitude, conduct, and will carry out my obligations in accordance with my professional code of ethics, honor, dignity and responsibility as a Notary.

That I will keep the contents of the deed and the information obtained in the performance of my position confidential.

That I can be appointed to this position, either directly or indirectly, under whatever name or pretext, never and will not give or promise anything to anyone. "

Occupation secrecy is resentenced in article 16 act 1 point $f$

(Article 16)

\footnotetext{
${ }^{9}$ Hadi, S. (1989). Metode Research, Yogyakarta: Andi Offset, p. 66.

This publication is licensed under Creative Commons Attribution CC BY. 
(1) In carrying the duty, it is mandatory for notary to;

Keep in secret for all deeds that had been conducted and every information gathered while conducting the deeds which is concerned with the oath, except enforced by constitution

The explanation above, it is stated that notary has responsibility in securing the secret about all information concerning the deeds and also the protection of legal subject as user of the service ${ }^{10}$. They must also keep in secret about all information which is gathered while conducting the deeds. Notary is one of entrusting profession (vertrouwensambt) ${ }^{11}$. It is a reason that a person is willing to give every precious information to them. If a notary could not control themselves, they will loss public trust and they will lose the official title of vertrouwensambt $t^{12}$.

The principle of notary secrecy which already protected by constitution, it will be followed by civil law article 170 act 1 which stated that every person who must need a secrecy in the name of occupation, position, and dignity could be protected from law enforcer to be a witness in a court about every information that people entrust it to them. the secrecy position under the umbrella of constitution become a barometer that must be followed by notary in carrying their duty and keep the content of deeds in secret and only share the content with people who are responsible toward the deeds, which is already stated in article 54 act 1 , it states;

(Article 54)

Notary is only responsible in providing, showing, or telling the content of deeds, Grosse deeds, copy of deeds, deeds excerption, to people who are related to the deeds, legatees, or people who have right, except enforced by constitution.

In 2010, notary possessed extra special authority which is supporting the government in national security and economy stability by reporting indefinite transaction which is conducted in front of them which has possibility a treasure of money laundering that may lead into terrorism act. In executing their special authority, the notary will be registered as reporter of indefinite finance transaction or TKM, thus the notary will have duty as follows;

\section{A. Implement User Identification Principle}

To identify the user before transaction is mandatory for notary make in-depth research about the background of user. In notary occupation law, they must identify the user in formal way, introduction section must be witnessed by two people by providing ID card such as civilian identity card, passport, or other information stating the publication date of other deed. User identification principle which is regulated in article 18 act 2 law number 8 of 2010, article 4 government regulation number 43 of 2015, and ministry of human right number 9 of 2017 article 2 act 1 .

The identification user research is regulated in ministry of human right regulation, it is mandatory for notary to apply user identification principle, that contains information about user, verification of the user, and supervising transaction desalts by user. The principle is mandatory for notary when they prepare and execute the transaction in the name of the user, about sell and buy activity of property, money management, stock exchange, and other financial service/product. It also includes gyro management, savings account, deposit account, and/or effect account, corporation management, and founding, buying, or selling of legal company.

To execute the order, notary must wait until the transaction is dealt with the user. There are some transaction that use rupiah currency or foreign currency that has minimum amount of $\mathbf{R p 1 0 0 . 0 0 0 . 0 0 0 , 0 0 ~ ( o n e ~ h u n d r e d ~ m i l l i o n ~ r u p i a h ) , ~ t h e r e ~ i s ~ i n d e f i n i t e ~ m o n e y ~}$ transaction which has possibility connected with money laundering or terrorism funding, or notary place a doubt in the validity of information reported by the user.

B. Obligatory Act to Reveal the Profile, Aim and Scope of Cooperation, and Transaction between User and Beneficial Owner through Identification and Verification

10 Yuanitasari, D. (2017). The Role of Public Notary in Providing Legal Protection on Standard Contracts for Indonesian Consumers.

SRIWIJAYA Law Review, 1(2), p. 180

${ }_{11}$ Amelia, S., and Witasari, A. (2019). Implementation of Notary Liability in the Making of Deed Based Act No. 2 of 2014 on Notary Position.

JURNAL AKTA, 6(1), p. 32

12 Tobing, G.H.S.L. (1983). PeraturanJabatanNotaris, Cet.3, Jakarta, p. 117-118.

This publication is licensed under Creative Commons Attribution CC BY.

http://dx.doi.org/10.29322/IJSRP.11.06.2021.p11463 
The profile implementation is regulated in ministry of human right regulation number 9 of 2997 article 3, it is obligatory for notary to understand the profile, aim and scope of cooperation, and transaction between user and beneficial owner through identification and verification when commencing the agreement with users. Notary must have procedure and policy in order to prevent and minimise money laundering or terrorism funding which is identified in accordance with a risk assessment and also conducts a risk assessment. Besides, grouping the users based on their risk of doing money laundering and terrorism funding could be implemented by analysing the profile, business record, country, and product. In some cases, common sense and feeling are might be an option if there is something not right within the deal for both benefit and legal subject.

The application of the principle of recognizing the beneficial owners in the form of a corporation is regulated in Presidential Regulation No. 13 of 2018 concerning the Application of the Principle of Recognizing the Beneficiary Owners of Corporations in the Context of Prevention and Eradication of Money Laundering and Criminal Acts of Terrorism funding, because Corporations can be used as facilities, both directly and indirectly by the perpetrators of Criminal Acts of Money Laundering and Terrorism. The criteria for the beneficial owner of the presidential regulation are corporate controllers, owning more than $25 \%$ of a corporation. The information of the beneficial owner is made by the corporate management in the form of a written statement stating the origin of the funds / finance or property obtained legally and is willing to take responsibility for the government. In this case, the Notary is obliged to apply the presidential regulation to the Service User to make a statement of the beneficial owner of the Corporation.

\section{Reporting TKM toward PPATK (Finance Transaction Report and Analysis Centre)}

By delivering TKM report to PPATK, which is regulated in article 23 act 1 law number 8 of 2010 . Article 8 act 1 government regulation number 43 of 2015, and the publication of PPATK regulation number 11 of 2016,ministry of human rights regulation number 9 of 2017 (“Permenkumham No.9/2017”), republic of Indonesia presidential regulation number 13 of 2018 about identifying beneficial owner of corporation in order to intercept and eradication of money laundering and terrorism funding.

Notary has authority to report indefinite transaction by using one of government system which is GRIPS (Gathering Reports and Information Processing System), the obligation to report is the actual collaboration between government and notary in eradicating money laundering, it also represent as Indonesian action in international forum in Financial Action Task Force (FATF). The obligation for a notary to report any indefinite transaction which is regulated in:

1. Law number 8 of 2010 about intervention and eradication of money laundering action (article 17 act 1).

2. Government regulation number 43 of 2015 about reporter in intervention and eradication of money laundering.

3. Regulation of head of finance transaction report and analysis centre number 11 of 2016 about procedure of indefinite transaction report for officials.

4. Ministry of human right and law regulation number 9 of 2017 about implementation of notary beneficial user identification.

The obligation of TKM report could be done by using wireless method of GRIPS (web based https://grips2.ppatk.go.id/), as vulnerable gatekeeper, notary could be used as money laundering media by the user. Concerning with the report of indefinite financial transaction or TKM toward PPATK, notary must register their account by using GRIPS application and selecting reporter officials before.

In order to register at GRIPS, there is a tutorial steps which could be found in this link http://www.ppatk.go.id/video/lists/1.html. As first step, there are two phases in registration process in GRIPS PPATK application, which are:

1. Online registration at the website: https://grips2.ppatk.go.id/faces/registrasi.xhtml

2. Delivering the printed online registration form to PPATK, as late as 7 days after the online registration was finished.

There is a video tutorial for online registration demonstration that could be found in http://www.ppatk.go.id/video/lists/1.html.

Several principles concerning with eradication of money laundering and terrorism funding are:

a. Prosperous and security principle, both principle would not be separated, they are essential and basic need for human both individual and community scale, country and region. That is why, both principle must always be provided, and must not be 
separated in every condition as both principle are the representation of national stability of a country ${ }^{13}$.

b. Beneficial principle, there are several benefits that must stay in balance which are 1) individual interest toward another individual; 2) individual interest toward community; 3) society interest toward foreign community; 4) community interest toward another community; 5) government interest toward society; 6) present community interest toward future community; 7) human interest toward ecosystem.

c. Public interest principle, it is a principle that prior public prosperity and general benefit by using expressive, accommodative, selective, justice perspective.

Every legal action which is performed in front of a notary, if it was meant for court material about the deed, it must be approved by honorary regional notary assembly as long as 30 days from the request was received, which is regulated in Notary Profession law article 66 that states:

(Article 66)

(1) For court material, investigator, public prosecutor, and judge, after receiving authority form notary honorary assembly, they have rights to:

a. Taking Minuta deed and other documents attached to minuta deed or other notary protocol in notary save; and

b. Asking the presence of notary in investigation process within the deed or protocol which is located in the notary save.

(2) Minuta deed and other documents transfer which is stated in act (1) point a, it must be approved with official report letter.

(3) Honorary notary assembly after30 days from the request was received, which is stated in act (1), they must provide answer whether the request is approved or rejected.

(4) If honorary notary assembly does not provide clear responds toward the request within requested time which is stated in act (3), the respond will be considered as approved from honorary notary assembly.

(5) It could be an obstacle because money laundering and terrorism performed in quick action, within high risk, and threaten national stability and safety of its society.

The obligation of notary in profession secrecy (UUJN law number article 16 act 1 point $\mathrm{f}$ ) which is connected to money laundering and terrorism eradication, and in the name of prosperity and security, beneficial, public interest (all matters interest). It means that the Notary's obligation to report the suspicious financial transaction to PPATK through the GRIPS system is actually not in conflict with the oath of office and confidentiality of the position, because the notary has the authority given by the state, which is already stated in first sentence of article 4 act (2), jo article 16 act (2) point g, that states:

(Article 4)

(1) "I will be obedient and loyal to the Republic of Indonesia, Pancasila and the 1945 Constitution of the Republic of Indonesia, the Law on Notary Position and other laws and regulations"

(Article 16)

(2) In performing their duty, notary must:

f. Keep everything about the Deed he made and all information obtained to make the Deed in accordance with the oath / promise of office, unless the law stipulates otherwise.

Notary must keen to find, identify, and reveal its legal subject user or the ability of users for the legal action performed by user toward notary. Next, notary must be active in locating the indefinite transaction, if they found any of it, they must report it to PPATK through GRIPS system. The report that was based on personal perspective from notary is very complicated because there are no certain criteria or standard. It is better for government to commence that force the corporation owner or beneficial owner about the standard and the criteria, it could be in form of the amount of transaction and certain declaration letter, and the transaction process must use bank as the media.

\footnotetext{
${ }^{13}$ Herdiawanto, H., et al. (2019). Kewarganegaraan dan Masyarakat Madani, Jakarta: Prenadamedia Group, p. 194

This publication is licensed under Creative Commons Attribution CC BY. 


\section{CONCLUSION}

The notary who proceeds the indefinite transaction report by using GRIPS system does not against secrecy profession oath of notary. Besides, the notary could be considered as law enforcer of state or known as gatekeeper. Therefore, it is suggested that Notary user except corporation, who commence transaction as minimum as Rp. 100.000.000,- ( one hundred million rupiah ) is obligated to create letter of declaration and uses bank as media transaction. In addition, notary must perform socialisation about regulations to all notary users and public community (general meaning), and does not report to the grips without any agreement from the users.

\section{REFERENCES}

[1] Smith, A. G. (2018). How Radicalization to Terrorism Occurs in the United States: What Research Sponsored by the National Institute of Justice Tells Us. Washington, DC: NIJ National Institute of Justice.

[2] Handoko, A. (2019). Analisis Kejahatan Terorisme Berkedok Agama. SALAM Jurnal Sosial \& Budaya Syar'i. 6(2): 155-178.

[3] Amrullah, M. A. (2003). Pencucian Uang dan Kejahatan Terorganisir. JURNAL HUKUM, 22(10): 130-146.

[4] Dobrowolski, Z., and Sulkowski, L. (2019). Implementing a Sustainable Model for Anti-Money Laundering in the United Nations Development Goals. Sustainability, 12(244): 1-23.

[5] Eleanora, F. N. (2011). Tindak Pidana Pencucian Uang. Jurnal Hukum, XXVI(2): 640-653.

[6] Alkostar, A. (2013). Penerapan Undang-Undang Tindak Pidana Pencucian Uang dalam Hubungannya dengan Predicate Crimes. MMH, 42(1): 45-54.

[7] Black, H. C. (1990). Black's Law Dictionary Sixth Edition. St. Paul Minn: West Publisihing Co.

[8] Husein, Y. (2007). Bunga Rampai Anti Pencucian Uang (First Edition). Bandung: Books Terrace \& Libertty.

[9] Hadi, S. (1989). Metode Research. Yogyakarta: Andi Offset.

[10] Yuanitasari, D. (2017). The Role of Public Notary in Providing Legal Protection on Standard Contracts for Indonesian Consumers. SRIWIJAYA Law Review, 1(2): 179-190.

[11] Amelia, S., and Witasari, A. (2019). Implementation of Notary Liability in the Making of Deed Based Act No. 2 of 2014 on Notary Position. JURNAL AKTA, 6(1): 29-34.

[12] Tobing, G. H. S. L. (1983). Peraturan Jabatan Notaris (Third Edition). Jakarta.

[13] Herdiawanto, F., Wasitaatmadja, F., Hamdayama, J. (2019). Kewarganegaraan dan Masyarakat Madani (First Edition). Jakarta: Prenadamedia Group. 